\title{
BEHAVIOURAL DEFENSES OF THE HONEY BEE ECOTYPE FROM SJENICA - PESTER AGAINST Varroa destructor
}

\author{
STANIMIROVIĆ Z*, STEVANOVIĆ JEVROSIMA* and ĆIRKOVIĆ D**
}

*Faculty of Veterinary Medicine, Belgrade,

${ }^{\star \star}$ Republic Ministry of Agriculture and Water Management, Novi Pazar

(Received 8. August 2004)

Two behaviours of honey bees, hygienic and grooming, are mechanisms of defense against brood diseases and parasitic mites, including Varroa destructor. Apis mellifera colonies remove the worker brood infested with Varroa destructor mites from the nest (hygienic behaviour), and groom the mites off other adult bees (grooming behaviour). In this study hygienic and grooming behaviours of Syenichko-Peshterski honey bee ecotype were analysed in 440 honey bee colonies from 11 localities in the region of Syenichko-Peshterski plateau, Podpeshterje, Golija Mt. and Rogozna Mt. At each locality 40 honey bee colonies were investigated: 10 potent colonies with oneyear old queen, 10 potent colonies with two-year old queen, 10 medium potent and 10 weak honey bee colonies. Hygienic behaviour was expressed in a range from $95.12 \%$ to $99.50 \%$ in potent honey bee colonies with one-year old and two-year old queens. Statistically highly significant $(p<0.01)$ differences were registered among the analysed honey bee colonies at the investigated region, in favour of the potent honey bee colonies, compared to the medium potent and weak colonies. Also, statistically highly significant $(p<0.01)$ differences were recorded between potent colonies with one-year old queens and colonies with two-year old queens, in favour of the colonies with oneyear old queens. In general, investigated colonies belong to a category of the so called "hygienic colonies", as the efficiency of elimination of damaged pupae amounted to $91.50 \%$. Grooming behaviour of Syenichko-Peshterski honey bee ecotype potentially exists, but its significance cannot be discussed as, on the whole, investigated colonies showed potential of $34,04 \%$. Our results point to an indisputable relationship between analysed behaviours and the strength of honey bee colonies: hygienic behaviour is more expressed in potent colonies (from $95.12 \%$ to $99.50 \%$ ) regardless of queen age; grooming behaviour was expressed only in potent honey bee colonies with one-year old queen at all 11 localities, where the number of damaged mites ranged from $36,05 \%$ to $39,61 \%$. The damaged mites were separated into six categories. The most frequent category of damage was damaged legs $(53.38 \%$ in potent colonies with one-year 
old queens and $52.02 \%$ in potent colonies with two-year old queens). The potent honey bee colonies from the investigated region, especially with one-year old queen, could be used for highly selectioned breeds improving and queens rearing.

Key words: Apis mellifera, Varroa destructor, SyenichkoPeshterski honey bee ecotype, behavioral defense (hygienic and grooming behaviours), types of mite damages.

\section{INTRODUCTION}

Feral and domesticated honey bee colonies have evolved elaborate defense mechanisms to protect both themselves and their food from pathogen and parasite invasion. The defense mechanisms of individual bees serve to minimize the threat for the whole colony (Boecking and Spivak, 1999).

Constitutional defense mechanisms, such as the chitinous cuticle, which serves as a barrier between internal and external environment, and the intestinal microflora of the bee gut, can protect each individual bee against infectious diseases (Dustmann, 1993; Glinski and Jarosz, 1995). Cellular defense mechanisms (haemocytes) and humoral reactions (enzyme and antimicrobic factors) can contribute to resistance toward infections (Casteels et al., 1985; Jacobs et al., 1990; Mitro, 1994). The proventricular valve enables the bees to filter ingested spores, which serves as a mechanism of physiological resistance to diseases (Dustmann, 1993). These individual responses, coupled with the short life-span of the bees and their rapid replacement with healthy individuals, can limit the spread of infections between bees within colony (Boecking and Spivak, 1999).

Behavioral defense of the honey bee Apis mellifera against ectoparasitic mite Varroa destructor Anderson and Trueman, 2000, involves two important mechanisms: hygienic and grooming behaviours. Foremost, hygienic (removal) behaviour was described as the main mechanism by which $A$. mellifera resist the brood diseases like American foulbrood and chalkbrood. Hygienic honey bee workers have the ability to detect diseased brood, uncap the wax covering over the brood cells and remove infected larvae or pupae. Afterwards, it has been demonstrated that hygienic bees detect and remove pupae infested with the parasitic Varroa mites (Spivak, 1996). Arathi et al. (2000) found that hygienic behaviour is predominantly performed by the middle-aged worker bees that have not yet begun foraging and that $18 \%$ of the bees in the colony are actually involved in the task at any given time. The removal of infested pupae interrupts the reproduction of the fertile mites inside sealed brood cells. In addition, the immature mites are killed which decreases the average number of offspring per mother mite (Rath and Drescher, 1990; Fries et al., 1994, Stanimirovic et al., 2002b). In grooming, adult bees detect and remove phoretic mites from themselves (auto-grooming) or from nestmates (allo-grooming) (Peng et al., 1987). In the process, the legs of the mite may be cut off or the cuticle of the idiosoma may be damaged by the bees' mandibles, causing the damaged mite to fall to the bottom of the colony (Ruttner and Hännel, 1992; Stanimirovic et al., 
2003). According to Lodesani et al. (1996) and Rosenkranz et al. (1997), the main type of damage to the mite caused by successful grooming is amputation or mutilation of one or more legs. Injuries to the mites' idiosoma or gnathosoma are relatively rare.

The colonies of $A$. mellifera die from varroasis (disease caused by $V$. destructor) within a few years if the mite population growth is not regulated by the beekeeper. Chemical control has its problems and limitations - reduced efficacy and development of resistance to chemical control by Varroa mites (Milani, 1999; Wallner, 1999). Therefore, the only possible solution to the problems of honey bee varroasis is the identification and use of resistant stocks of honey bees, and their selection for enhanced resistance toward that disease, which could be acquired with stimulating hygienic and grooming behaviours, without looses of reproductive-productive features of honey bee colonies (Rinderer et al., 2001). In order to find such resistant honey bee stock on the territory of Serbia, we analysed behavioural defense against $V$. destructor in honey bee colonies of indigenous Sjenica-Pester ecotype inhabited in the southwest part of Serbia, in the regions of Sjenica-Pester plateau, Podpesterje, Golija Mt. and Rogozna Mt.

\section{MATERIALS AND METHODS}

The analyses of the hygienic and grooming behaviours of honey bee ecotype from Sjenica-Pester were carried out at 11 localities from the region of Sjenica-Pester plateau, Podpesterje, Golija Mt. and Rogozna Mt. At each locality 10 potent honey bee colonies with one-year old queen $(A), 10$ potent colonies with two-year old queen (B), 10 medium potent (C) and 10 weak honey bee colonies (D) were investigated, i.e. 40 beehives per location - the total of 440 honeybee colonies from the aforesaid regions.

The examination and evaluation of the hygienic behaviour in the chosen honey bee colonies were performed in accordance with the procedures established by Taber III (1982) and modified by Kefuss et al. (1996), Stanimirovic et al. $(2001,2002 a, b)$. The analysis and evaluation of the honey bee grooming behaviour were done according to the procedure of Hoffman (1993), whilst classification and quantification of the damage to Varroa destructor in accordance was done with the criteria established by Correa-Marques et al. (2000).

\section{RESULTS}

Hygienic behaviour (Figure 1) of potent honey bee colonies (regardless of queen age) ranged from $95 \%$ to $99.50 \%$, so all investigated potent colonies were "superhygienic" honey bee colonies (Figure 2). Great intra- and interpopulation variability of the hygienic behaviour was observed, as well as significant $(p<0.01)$ differences of the monitored behaviour among colonies with different strength. Hygienic behaviour was more expressed in potent colonies $(97.01 \%)$ than in medium potent $(89.21 \%)$ and weak colonies $(82.74 \%)$. Also, significant $(p<0.01)$ 
differences were recorded between potent colonies with one-year old queens $(98.08 \%)$ and colonies with two-year old queens (95.94\%) (Table 1).

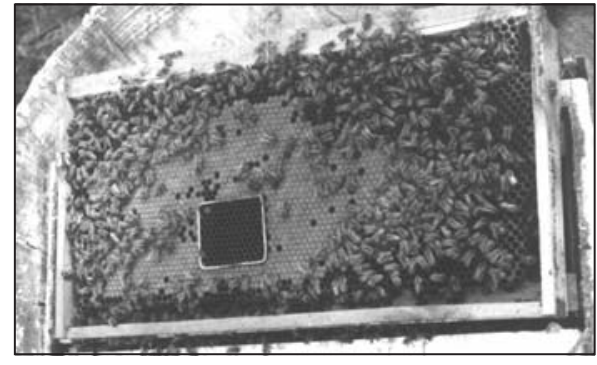

A

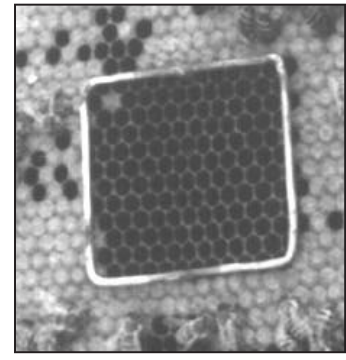

B

Figure 1. The example of a cleaned comb in a potent colony with one-year old queen from Sare locality, with expressed superhygienic behaviour (98.35\%).

A - entire frame with brood and sampled area;

B - magnified sampled area with cleaned comb cells

Table 1. Comparison of differences in hygienic behaviour among four different categories of analysed honey bee colonies

\begin{tabular}{|c|c|c|c|c|c|c|c|}
\hline \multirow{2}{*}{$\begin{array}{c}\text { Compared } \\
\text { colonies }\end{array}$} & \multicolumn{3}{|c|}{ Eliminated pupae } & \multirow[b]{2}{*}{$\Sigma \mathrm{A}$} & \multirow[b]{2}{*}{$\Sigma \mathrm{B}$} & \multirow[b]{2}{*}{$\Sigma \mathrm{C}$} & \multirow[b]{2}{*}{$\Sigma \mathrm{D}$} \\
\hline & $\begin{array}{l}\text { Mean } \\
\text { value } \\
\end{array}$ & $\pm \mathrm{SD}$ & $\%$ & & & & \\
\hline$\Sigma \mathrm{D}$ & 100.12 & 2.61 & $82.74 \%$ & $18.56^{\star \star}$ & $15.97 * *$ & $7.82^{\star *}$ & \\
\hline$\Sigma \mathrm{C}$ & 107.94 & 2.42 & $89.21 \%$ & $10.57^{* *}$ & $8.15^{\star \star}$ & & \\
\hline$\Sigma \mathrm{B}$ & 116.09 & 1.34 & $95.94 \%$ & $2.59 * *$ & & & \\
\hline$\Sigma \mathrm{A}$ & 118.68 & 1.37 & $98.08 \%$ & & & & \\
\hline
\end{tabular}

A - potent honey bee colonies with one-year old queens

$\mathrm{B}$ - potent honey bee colonies with two-year old queens

$\star *(p<0.01)$

C - medium potent honey bee colonies

D - weak honey bee colonies

The average potential of the grooming behaviour in all analysed honey bee colonies of ecotype from Sjenica-Pester was 34,04\% (min-max $=20.68-39.61 \%$ ). Grooming behaviour of potent colonies with one-year old queens, ranged from $36.40 \%$ to $39.61 \%$ (Figure 3). Those colonies had expressed grooming behaviour, as well as the potent colonies with two-year old queens at 8 from 11 localities altogether (36.05\%-36.62\% damaged mites) (Figure 3). The average potential of grooming behaviour in 220 potent colonies (regardless of queen age) is $36,73 \%$ (min-max $=35.04-39.61 \%$ ). Among the 34032 mites collected in the debris of 110 potent colonies with one-year old queens, 12661 (37.20\%) were found damaged, 
Stanimirović $Z$ et al. Behavioural defenses of the honey bee ecotype from

Sjenica - Pester against Varroa destructor

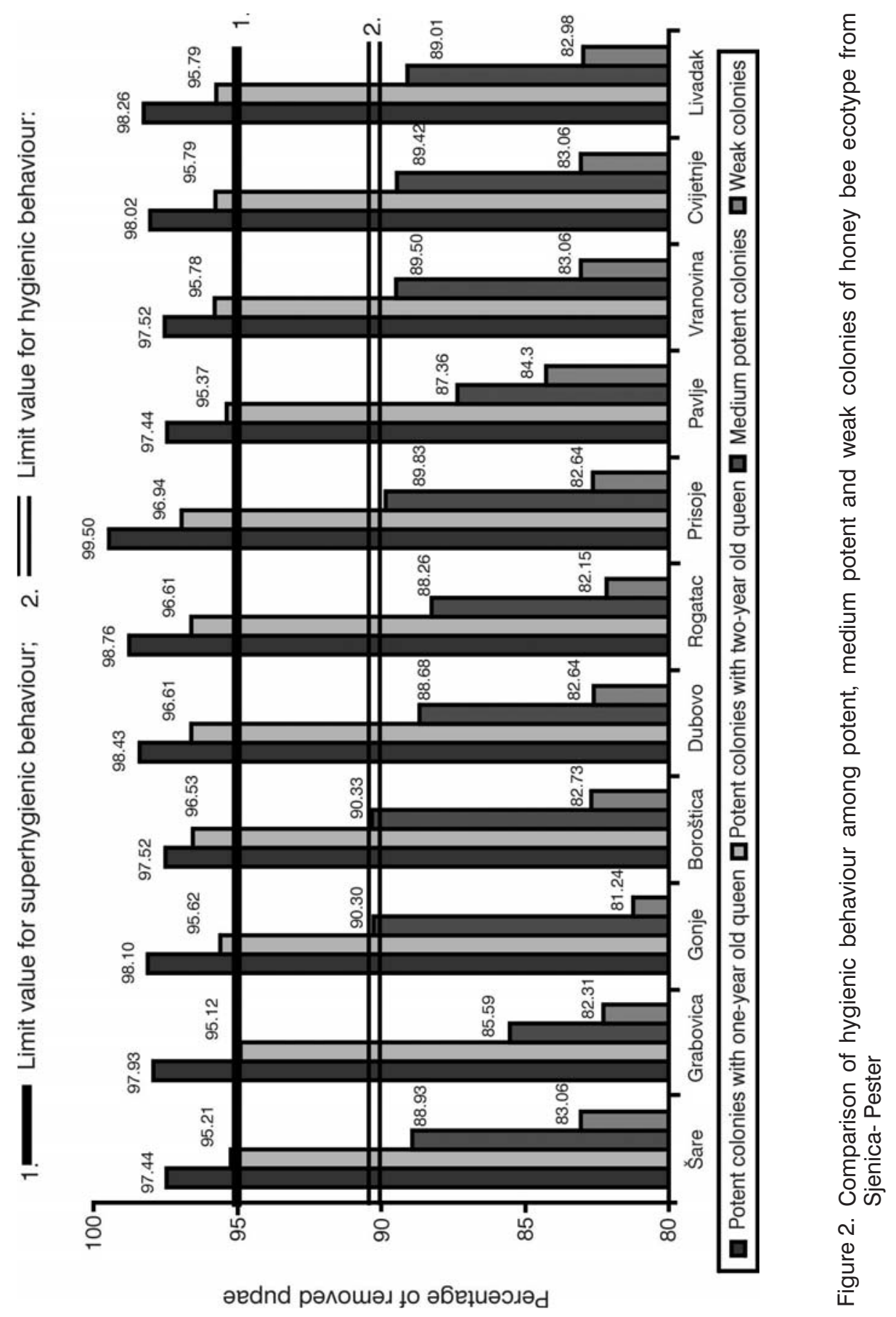




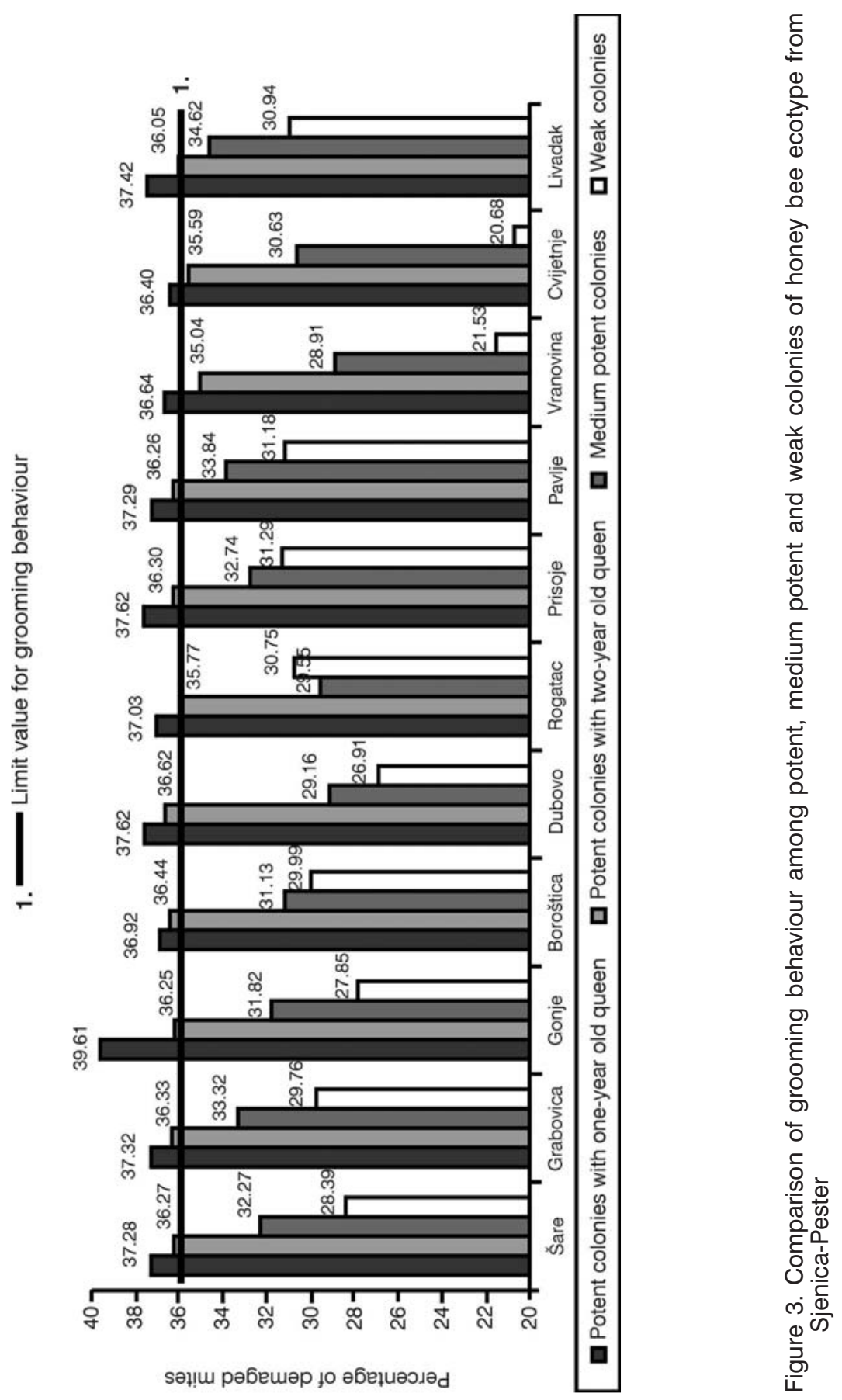


while the number of damaged mites among the 30836 mites collected in the debris of 110 potent colonies with two-year old queens, was 11118 (36.06\%). Classification and quantification of damaged mites were done only in these honey bee colonies (potent colonies with one-year and two-year old queens) (Table 2). The damaged mites were separated into six categories: 1 ) damaged legs-missing one or more legs or parts of legs; 2) damaged shields + damaged legs; 3 ) hollow in the dorsal shield + damaged legs; 4) depression or hollow in the dorsal shield; 5 ) carcass or empty dorsal shield - mites that lack legs and all or nearly all of the ventral shields; 6 ) damaged shields-loss of some ventral shields and/or broken dorsal shield. The most frequent category of damage was damaged legs $(53.38 \%$ in potent colonies with one-year old queens and $52.02 \%$ in potent colonies with two-year old queens), while other types of damages were less frequent. In potent colonies with one-year old queens there were: $22.25 \%$ damaged shields + damaged legs, $17.03 \%$ hollow in the dorsal shield + damaged legs, $3.00 \%$ depression or hollow in the dorsal shield, $2.74 \%$ carcass empty dorsal shield, $1.60 \%$ damaged shields. In potent colonies with two-year old queens the analysys revealed: $21.16 \%$ damaged shields + damaged legs, $16.23 \%$ hollow in the dorsal shield + damaged legs, $5.74 \%$ depression or hollow in the dorsal shield, $3.53 \%$ carcass - empty dorsal shield, $1.32 \%$ damaged shields (Table 2, Figure 4).

Table 2. Classification and quantification of the kinds of damage to Varroa destructor, collected in the debris of 110 potent honey bee colonies with one-year old queens $(A)$ and 110 potent honey bee colonies with two-year old queens (B)

\begin{tabular}{|l|c|c|c|c|}
\hline \multirow{2}{*}{ Kinds of damage } & \multicolumn{2}{|c|}{$\begin{array}{c}\text { Damaged mites in } \\
\text { potent colonies } \\
\text { with one-year old } \\
\text { queens }\end{array}$} & $\begin{array}{c}\text { Damaged mites in } \\
\text { Potent colonies } \\
\text { with two-year old } \\
\text { queens }\end{array}$ \\
\cline { 2 - 5 } & No & $\%$ & No & $\%$ \\
\hline Damaged legs & 6758 & 53.38 & 5784 & 52.02 \\
\hline Damaged shields + damaged legs & 2817 & 22.25 & 2353 & 21.16 \\
\hline Hollow in the dorsal shield + damaged legs & 2156 & 17.03 & 1804 & 16.23 \\
\hline Depression or hollow in the dorsal shield & 380 & 3.00 & 638 & 5.74 \\
\hline Carcass - empty dorsal shield & 347 & 2.74 & 392 & 3.53 \\
\hline Damaged shields & 203 & 1.60 & 147 & 1.32 \\
\hline \multicolumn{1}{|c|}{ Total } & 12661 & 100 & 11118 & 100 \\
\hline
\end{tabular}


A
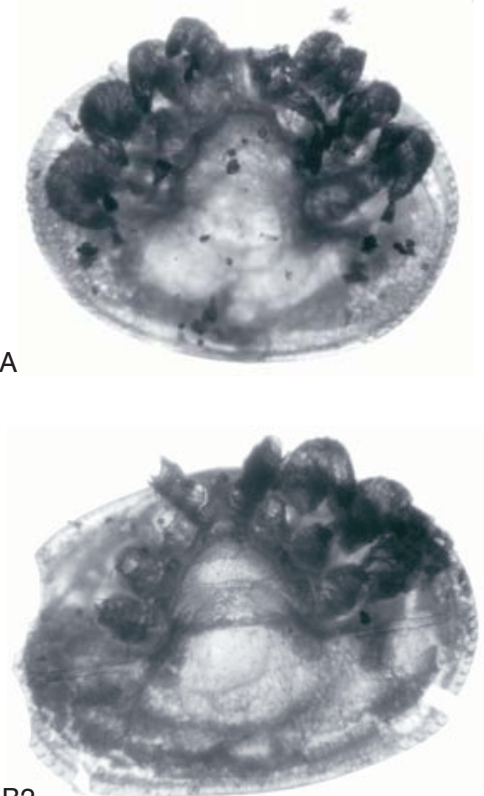

B2

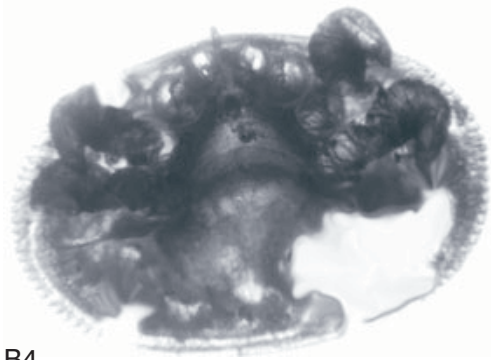

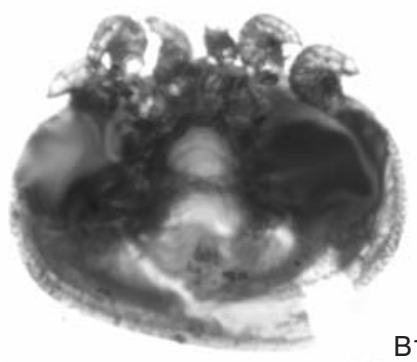

B1

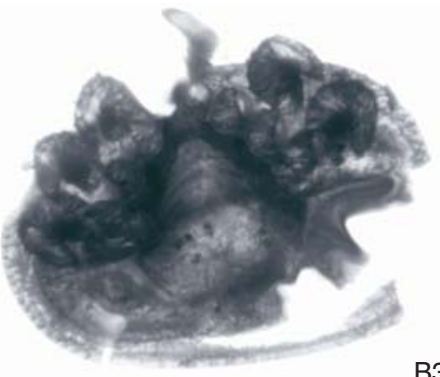

B3

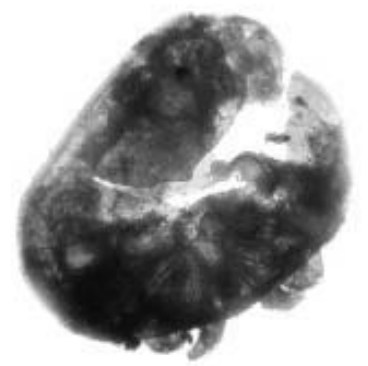

B5

A - normal outer morphology of Varroa destructor (ventral view);

B - Different kinds of damage to Varroa destructor (1-5)

B1 - lack of two pair of legs reciprocal + damaged shields;

B2 - damaged dorsal shield:

B3 - damaged pedipalp + damaged shields:

B4 - damaged ventral shield;

B5 - hollow in the dorsal shield + damaged legs

Figure 4. Different kinds of damage to Varroa destructor - the result of grooming behaviour of honey bees 


\section{DISCUSSION}

Hygienic behaviour, an intranidal task performed by middle-aged worker bees, is an important behavioural mechanism of resistance to disease and to attack by Varroa destructor, an ectoparasitic mite (Spivak and Reuter, 1998; Boecking and Spivak, 1999; Stanimirovic et al., 2001, 2002a,b).

The results of hygienic behaviour analyses obtained in this study are in accordance with those of Spivak and Gilliam (1993) and point to an indisputable relationship between expression of hygienic behaviour and the strength of honey bee colonies, which means that the potent colonies have more expressed hygienic behaviour and consequently greater resistance to many diseases.

The results of hygienic behaviour investigations in the present study are in accordance with those reported for grey bees from Rudnik region and yellow bees from Macva region (Pejovic, 2001; Cirkovic, 2002; Stanimirovic et al, 2001, 2002a;b), as the average level of exertion of the hygienic behaviour in honey bee ecotype from Sjenica-Pester is $91,50 \%$ ( $\min -\max =81.24-99.50 \%$ ); in grey honey bees from Rudnik $93.60 \%$ ( $\min -\max =81.74-98.92 \%$ ), and in yellow bees from Macva $91.45 \%$ (min-max $=82.64-98.55 \%)$. Superhygienic behaviour was affirmed in all investigated potent honey bee colonies of Sjenica-Pester ecotype (regardless of queen age). Such superhygienic potent honey bee colonies from all investigated localities from the region of Sjenica-Pester Plateau, Podpesterje, Golija Mt. and Rogozna Mt., could be used as breeding colonies for rearing quality queens. If those queens are naturally mated to unselected drones, their offspring will actively defend themselves against the mites. However, according to Spivak and Reuter (2001), such behavioural response is possible only at low mite levels ( $<15 \%$ of worker brood and $<15 \%$ of adult bees) in the first year of service period (for up to $1 \mathrm{yr}$ without treatment). Converslely, if mite infestation is higher (>15\% of worker brood and $>15 \%$ of adult bees) hygienic colonies eventually will collapse unless treated, because at high mite levels, the bees may habituate to the odor cues that elicit the hygienic behaviour and are not able to detect individually infested cells. In this case, the bees may cease to detect and remove the infested brood (Mastermann et al., 2000). It remains to be determined if colonies with hygienic queens mated to hygienic drones would survive mite infestations for longer periods, considering that hygienic behaviour is mediated with olfactory cues emanating from abnormal (dead, diseased, or parasitized) brood, as well as the results of Mastermann et al. (2001) and Spivak et al. (2003) which revealed that queens (worker bees) selectioned for hygienic behaviour exhibit a greater olfactory sensitivity to low concentrations of the odor of diseased brood than same-aged nonhygienic queens (bees). Thence, Spivak and Reuter (2001) and Spivak et al. (2003) suggest obligatory replacement of selectioned queens after 1 year service period, with the aim to retain adequate genetic variability. The results of our study are in accordance with those suggestions because revealed significant $(p<0.01)$ differences in hygienic behaviour between potent colonies with one-year old queens (98.08\%) and colonies with two-year old queens (95.94\%) (Table 1). 
Acta Veterinaria (Beograd), Vol. 55. No. 1, 69-82, 2005.

Moreover, behavioural defense of honey bees against Varroa destructor implies grooming behaviour, an important mechanism which enables individuals and groups of bees within a colony to remove dust and pollen from their bodies, to disperse pheromones, and to remove ectoparasites. Grooming behaviour involves biting and licking with the mouthparts and movements of the mesothoracic legs (Boecking and Spivak, 1999). Our investigations indicated a great potential of grooming behaviour in honey bee ecotype from Sjenica-Pester and a relationship between expression of grooming behaviour and the colony strength, because the potent colonies had more expressed grooming behaviour and greater resistance to ectoparasites. The results of this study are in accordance with previous studies on grooming behaviour in honey bees from other parts of Serbia, Rudnik and Macva regions (Pejovic, 2001; Cirkovic, 2002; Stanimirovic et al, 2001, 2002a;b), because the average potential of the grooming behaviour in honey bee ecotype from Sjenica-Pester is $34,04 \%$ ( $\min -\max =20.68$ $39.61 \%$ ); in grey honey bees from Rudnik $34,81 \%$ ( $\min -\max =29.34-38.68 \%)$, and yellow bees from Machva 34,78\% (min-max $=29.74-42.14 \%$ ) (Pejovic, 2001; Cirkovic, 2002; Stanimirovic et al, 2001, 2002a;b). The mite damage analyses done in potent colonies of honey bee ecotype from Sjenica-Pester revealed six different kinds of damage in both, potent colonies with one-year old queens (damaged legs: $53.38 \%$; damaged shields + damaged legs: $22.25 \%$; hollow in the dorsal shield + damaged legs: $17.03 \%$; depression or hollow in the dorsal shield: $3.00 \%$; carcass - empty dorsal shield: $2.74 \%$; damaged shields: $1.60 \%$ ) and potent colonies with two-year old queens (damaged legs: 52.02; damaged shields + damaged legs: $21.16 \%$; hollow in the dorsal shield + damaged legs: $16.23 \%$; depression or hollow in the dorsal shield: $5.74 \%$; carcass - empty dorsal shield: $3.53 \%$; damaged shields: $1.32 \%$ ). Our data which show that the most frequent kind of damage is damaged legs are in accordance with those of Ruttner and Hännel (1992), Lodesani et al. (1996) and Rosenkranz et al. (1997) and Correa-Marques et al. (2002). Ruttner and Hännel (1992) found that $30-50 \%$ of fallen mites had damaged legs, especially the first pair of legs. They indicate that damage to the legs is the type of damage most characteristic of an active defense by the bees against varroa. Rosenkranz et al. (1997) repored that $25 \%$ of damaged mites lost part or all of one leg, $75 \%$ had more than one leg damaged and dorsal shield injuries were rare. Correa-Marques et al. (2002) in Carniolan bees found $46 \%$ fallen mites damaged legs and concluded that differences in the rates of specific types of damage to the mites, such as damaged legs, may be indicative of tolerance capabilities by the bees.

The average potential of grooming behaviour in honey bee ecotype from Sjenica-Pester in potent colonies is 36,73\% ( $\min -\max =35.04-39.61 \%)$, which is similar with results of Correa-Marques et al. (2000) who revealed potential of this behavioural mechanism in Africanized bees less than 40\%, but low compared with rates of over $70 \%$ found in relatively tolerant European bees (Wallner, 1994).

Comparing our results of behavioural investigations with those of Spivak and Reuter (2001) and Correa-Marques et al. $(2000,2002)$ it could be noticed that nonselectioned queens of potent colonies of indigenous honey bee ecotype from Sjenica-Pester demonstrate higher potential of hygienic and grooming 
behaviours than Italian-derived Apis mellifera queens selectioned for hygienic behaviour in the US (Spivak and Reuter, 2001), Varroa-tolerant Italian honey bees introduced from Brazil (35.8\%) analysed in Germany (Correa-Marques et al., 2002). These results together with previous morphometric and cytogenetic investigations (Stanimirovic et al., 1999a,b, 2005; Stevanovic, 2002) complete the picture about Syenichko-Peshterski honey bee ecotype as a precious genetic resource which has to be preserved and protected. Owing to the manifested hygienic and grooming behaviours and thence, great resistance to Varroa destructor, investigated honeybee ecotype from Sjenica-Pester could be used for improving breeds selection and for organic beekeeping in Serbia, all the more because honey bees with expressed grooming behaviours were with excellent productive performances, although with increased aggressive behavour.

It is currently unreasonable to assume that honey bees bred for hygienic behaviour will survive indefinitely without some sort of periodic treatment. However, it is encouraging that lines bred for hygienic behaviour may require less frequent treatments that unselected lines. Any reduction in pesticide use within colonies translates into lower operating costs for the commercial beekeeper and decreased risk of contaminating honey and hive products (Spivak and Reuter, 2001).

ACKNOWLEDGEMENT:

These study was supported by the Serbian Ministry of Science, Technology and Development, Grant No 1870 .

Address for correspondence:

Prof. Dr Zoran Stanimirović

Department of biology

Faculty of veterinary medicine

Bul. JNA 18, 11000 Belgrade,

Serbia\&Montenegro;

E-mail: biolog@vet.bg.ac.yu

\section{REFERENCES}

1. Anderson D, Trueman JWH, 2000, Varroa jacobsoni (Acari: Varroidae) is more than one species. Exp Appl Acarol, 24, 165-89.

2. Arathi HS, Burns I, Spivak M, 2000, Ethology of hygienic behaviour in the honey bee Apis mellifera L. (Hymenoptera: Apidae): behavioural repertoire of hygienic bees, Ethology, 106, 365-79.

3. Boecking O, Spivak M, 1999, Behavioral defenses of honey bees against Varroa jacobsoni Oud., Apidologie, 30, 141-58.

4. Cirkovic $D, 2002$, Reproductive-productive and hygienic-grooming characterization of SyenichkoPeshterski honey bee ecotype, MSc. thesis, Univ. Belgrade, Yugoslavia.

5. Castee/s $P$, Van Steenkiste $D$, Jacobs FJ, 1985, The antibacterial response of haemolymph from adult honeybees (Apis mellifera) in relation to secondary infections, In: Cavalloro R, editor, European Research on Varroatosis Control, Balkema AA, Rotterdam, 105-11.

6. Correa-Marques MH, Cavicchio Issa MR, De Jong D, 2000, Classification and quantification of damaged Varroa jacobsoni found in the Debris of honey bee colonies as criteria for selection? Am Bee J 140, 10, 820-4. 
7. Correa-Marques MH, De Jong D, Rosenkranz P, Goncalves LS, 2002, Varroa - tolerant Italian honey bees introduced from Brazil were not more efficient in defending themselves against the mite Varroa destructor than Carniolan bees in Germany, Genet Mol Res, 1, 2, 153-8.

8. Dustmann JH, 1993, Natural defense mechanisms of a honey bee colony against diseases and parasites, Am Bee J, 133, 431-4

9. Fries I, Camazine S, Sneyd J, 1994, Population dynamics of Varroa jacobsoni: a model and a review, Bee world 75, 5-28.

10. Glinski Z, Jarosz J, 1995, Mechanical and biochemical defenses of honey bees, Bee World, 76, 110-8.

11. Hoffman S, 1993, The occurrence of damaged mites in cage test and under field conditions in hybrids of different Carniolan lines, Apidologie, 24, 493-5.

12. Jacobs FJ, Lenaerts $A$, De Graaf D, Casteels $P, 1990$, Humoral reactions of honeybees in relation to Varroa and Nosema disease of honeybees, In: Ritter W, editor, Proceedings of the International Symposium on recent Research on Bee Pathology, Sept 1990, Ghent, Belgium, 120-124.

13. Kefuss J, Taber S, Vanpoucke J, Rey F, 1996, A practical method to test for disease resistance in honey bees. Am Bee J, 136, 1, 31-2.

14. Lodesani M, Vecchi MA, Tommasini S, Bigliardi M, 1996, A study on different kinds of damage to Varroa jacobsoni in Apis mellifera ligustica colonies, J Apic Res, 35, 49-56.

15. Masterman R, Smith BH, Spivak M, 2000, Brood odor discrimination abilities in honey bees (Apis mellifera L.) using proboscis extension reflex conditioning, J Insect Behav, 13, 87-101.

16. Masterman R, Ross R, Mesce K, Spivak M, 2001, Olfactory and behavioral response thresholds to odors of diseased brood differ between hygienic and non-hygienic honey bees (Apis mellifera L.), J Comp Physiol A, 187, 441-52.

17. Milani N, 1999, The resistance of Varroa jacobsoni to acarisides: A short review. Apidologie, 30, 229-34.

18. Mitro S, 1994, Zelluläre Abwehrmechanismen in der hämolymphe und der Nachweis spezifischer Zelltypen in seminaplasma bei Apis mellifera L, Apidologie, 25, 361-6.

19. Peng YS, Fang Y, Xu S, Ge L, Nasr ME, 1987, The resistance mechanism of the Asian honey bee, Apis cerana Fabr, to an ectoparasitic mite Varroa jacobsoni Oudemans, J Invertebr Pathol 49, 54-60.

20. Pejovic $D, 2001$, Investigations of hygienic and grooming behaviour of honey bee subspecies Apis mellifera carnica in disease resistance, MSc. thesis, Univ. Belgrade, Yugoslavia.

21. Rath W, Drescher W, 1990, Response of Apis cerana Fabr towards brood infested with Varroa jacobsoni Oud and infestation rate of colonies in Thailand, Apidologie, 21, 311-21.

22. Rinderer TE, De Guzman LI, Delatte GT, Stelzer JA, Williams JL, Beaman LD, Kuznetsov V, Bigalk M, Bernard SJ, Tubbs $H, 2001$, Multi-state fields trials of ARS Russian honey bees: 1 . Responses to Varroa destructor 1999, 2000. Am Bee J, 141, 9, 658-61.

23. Rosenkranz P, Fries I, Boecking O, Stürmer M, 1997, Damaged Varroa mites in the debris of honey bee (Apis mellifera L.) colonies with and without hatching brood, Apidologie, 28, 427-37.

24. Ruttner F, Hännel H, 1992, Active defense against Varroa mites in Carniolan strains of honey bees, Apidologie, 23, 173-87.

25. Spivak M, Gilliam M, 1993, Facultative expression of hygienic behavior of honey-bees in relation to disease resistance, J Apic Res, 32, 143-47.

26. Spivak M, 1996, Honey bee hygienic behavior and defense against Varroa jacobsoni, Apidologie, 27, 245-60.

27. Spivak M, Reuter, GS, 1998, Performance of hygienic honey bee colonies in a commercial apiary. Apidologie 29, 291-302.

28. Spivak M, Reuter GS, 2001, Varroa destructor infestation in untreated honey bee (Hymenoptera: Apidae) colonies selected for hygienic behavior, J Econ Entomol 94, 2, 326-31.

29. Spivak M, Masterman R, Ross R, Mesce K, 2003, Hygienic behavior in the honey bee (Apis mellifera L.) and the modulatory role of octopamine, J Neurobiol, 55, 341-54. 
Acta Veterinaria (Beograd), Vol. 55. No. 1, 69-82, 2005

Stanimirović $Z$ et al. Behavioural defenses of the honey bee ecotype from

Sjenica - Pester against Varroa destructor

30. Stanimirovic Z, Popeskovic D, Pejovic D, 1999a, Biodiversity of the honeybee Apis mellifera, Linne (1758), from the Yugoslav regions: I - The biometric variability of the chromosomes of the Banat and Syenichko-Peshterski ecotypes, Acta Vet, 49, 2-3, 199-206.

31. Stanimirovic Z, Vucinic M, Stevanovic J, 1999b, Biodiversity of the honeybee Apis mellifera, Linne (1758), from some Yugoslav regions: II - Ultrastructural chromosomal differences between Banat and Syenichko-Peshterski honeybee ecotype, Acta Vet, 49, 2-3, 207-14.

32. Stanimirovic Z, Stevanovic J, Pejovic D, Mirilovic M, 2001, Hygienic and grooming behaviour in disease resistance of two honeybee ecogeographic varieties (Apis mellifera carnica) from Serbia, Mellifera 1, 2, 24-29, 56-61.

33. Stanimirovic Z, Pejovic D, Stevanovic Jevrosima, 2002a, Hygienic behavior in disease resisteance of two honeybee ecogeographic varieties (Apis mellifera carnica) from Serbia, Apiacta 37, 1, 24-31.

34. Stanimirović Z, Pejović D, Stevanović Jevrosima, Vučinić Marijana, Mirilović M, 2002b, Investigations of hygienic behaviour and disease resistance in organic beekeeping of two honeybee ecogeographic varieties from Serbia, Acta Vet, 52, 2-3, 169-80.

35. Stanimirovic Z, Stevanovic Jevrosima, Cirkovic D, Stanimirovic Marijana, 2003, Investigations of hygienic and grooming behaviours of Syenichko-Peshterski honey bee ecotype. In: Poklukar J, Kozmus P, editors, Proceedings of the XXXVIII International Apicultural Congress (APIMONDIA 2003), Aug 24-29, pp 548-549. Ljubljana, Slovenia.

36. Stanimirović Z, Stevanović Jevrosima, Anđelković M, 2005, Chromosomal diversity in Apis mellifera carnica from Serbia, Apidologie 36, 1, 31-42.

37. Stevanovic J, 2002 Investigations of morphometric and chromosomal variability in diversity preserving of Carniolan honey bee (Apis mellifera carnica Pollmann, 1879) in Serbia, MSc. thesis, Univ. Belgrade, Yugoslavia.

38. Taber S III, 1982, Bee behavior. Determining resistance to brood diseases, Am Bee J, 122, 422-5.

39. Wallner A, 1994, Der Varroakillerfaktor, Dtsch Bienen J. 2, 372-4.

40. Wallner K, 1999, Varroacides and their residues in bee products, Apidologie, 30, 235-48.

\title{
BIHEJVIORALNA ODBRANA SJENIČKO-PEŠTERSKOG EKOTIPA MEDONOSNE PČELE OD KRPELJA Varroa destructor
}

\author{
STANIMIROVIĆ Z, STEVANOVIĆ JEVROSIMA i ĆIRKOVIĆ D
}

\section{SADRŽAJ}

Higijensko i negovateljsko ponašanje predstavljaju dva mehanizma odbrane od bolesti legla i parazitskih krpelja, uključujući Varroa destructor. Društva Apis mellifera uklanjaju iz satnih ćelija radiličko leglo infestirano krpeljima Varroa destructor (higijensko ponašanje) i skidaju krpelje sa adultnih pčela (negovateljsko ponašanje). U ovom radu, obavljena je analiza higijenskog i negovateljskog ponašanja pčela sjeničko-pešterskog ekotipa kod ukupno 440 pčelinjih društava sa 11 lokaliteta Sjeničko-Pešterske visoravni, Podpešterja, Golije i Rogozne. Na svakom lokalitetu ispitivano je 40 pčelinjih društava: 10 jakih društava sa jednogodišnjom maticom, 10 jakih društava sa dvogodišnjom maticom, 10 srednje jakih i 10 slabih pčelinjih zajednica. Higijensko ponašanje bilo je ispoljeno u 
opsegu od 95,12\% do 99,50\% kod jakih pčelinjih zajednica sa jednogodišnjim i dvogodišnjim maticama. Između ispitivanjih pčelinjih društava pomenutog područja registrovane su statistički visoko značajne razlike $(p<0.01) u$ ispoljenosti higijenskog ponašanja u korist jakih pčelinjih zajednica u odnosu na srednje jake i slabe. Takođe, visoko značajne razlike $(p<0.01) \mathrm{u}$ ispoljenosti ove osobine zabeležene su i između pčelinjih zajednica sa jednogodišnjim i dvogodišnjim maticama, u korist pčelinjih zajednica sa jednogodišnjim maticama. Generalno, pčelinja društva sa analiziranog područja Sjeničko-Pešterske visoravni, Podpešterja, Golije i Rogozne pripadaju kategoriji higijenskih društava, obzirom da je prosečna efikasnost eliminacije oštećenih lutki svih zajednica iznosila $91,50 \%$. Negovateljsko ponašanje kod pčela sjeničko-pešterskog ekotipa potencijalno postoji, ali se ne može govoriti o izraženosti ove osobine, obzirom da je globalna sposobnost eliminacije krpelja sa oštećenjima u ukupnom broju odbačenih krpelja svih ispitivanih pčelinjih zajednica bila 34,04\%. Ovi rezultati ukazuju na postojanje neosporne povezanosti analiziranih oblika ponašanja i jačine pčelinje zajednice: higijensko ponašanje je više ispoljeno kod jakih društava (od 95.12\% do 99,50\%) nezavisno od starosti matice, dok je negovateljsko ponašanje bilo izraženo samo kod kod pčelinjih zajednica iz kategorije jakih društava sa jednogodišnjom maticom na svim lokalitetima (od 36,05\% do 39,61\% oštećenih krpelja u odnosu na celokupan uzorak). Oštećeni krpelji su podeljeni u 6 kategorija. Najčešći tip oštećenja predstavljaju oštećene noge (53.38\% u jakim društvima sa jednogodišnjom maticom i 52.02\% kod jakih društava sa dvogodišnjom maticom). Jaka pčelinja društva sa ispitivanog područja, i to naročito ona sa jednogodišnjom maticom, mogu koristiti za poboljšanje visokoselekcionisanih sojeva, kao i u proizvodnji selekcionisanih matica sa izraženim higijenskim i negovateljskim ponašanjem. 